\title{
Thermal Behavior of IGBT Module for EV (Electric Vehicle)
}

\author{
Mohamed Amine Fakhfakh, Moez Ayadi, \\ Ibrahim Ben Salah and Rafik Neji \\ University of Sfax/Sfax \\ Tunisia
}

\section{Introduction}

EVs are divided into three categories: the pure EV, the hybrid EV, and the fuel cell EV. Although these three types of electric vehicle have different system configuration, one (or more) motor drive system is always needed to convert electrical power into mechanical ones. Among the drive systems used for EV, induction motor system and permanent magnet motor systems are mostly used for their high power density, high efficiency.

The motor drive system for electric vehicle (EV) is composed of a battery, three phase inverter, a permanent magnet motor, and a sensor system. The inverter is a key unit important among these electrical components which converts the direct current of the battery into the alternating current to rotate the motor. Therefore, for predicting the dynamic power loss and junction temperature, the electro-thermal coupling simulation techniques to estimate the power loss and to calculate the junction temperature become important.

This paper describes a compact thermal model suitable for the electro-thermal coupling simulation of EV inverter module for two current control methods. We can predict the dynamic temperature rise of $\mathrm{Si}$ devices by simulating the inverter operation in accordance with the real EV running.

\section{Dynamic model of the EV}

As shown in Figure 1 and table 1, there are six forces acting on the electric vehicle: the rolling resistance force, the aerodynamic force, the aerodynamic lift force, the gravity force, the normal force, and the motor force.

\subsection{Rolling resistance force}

Rolling resistance is due the tires deforming when contacting the surface of a road and varies depending on the surface being driven on. It can be model using the following equation:

$$
F_{1}=f M_{v} g
$$


Fig. 1. Diagram of forces applied to the EV

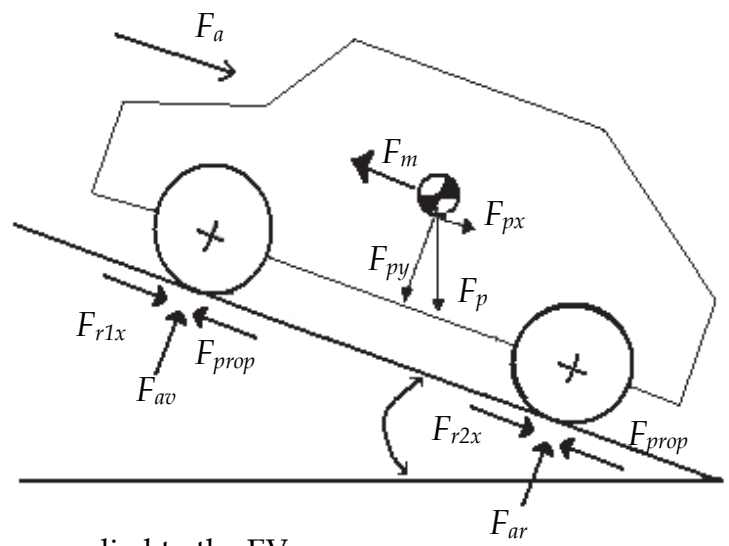

\begin{tabular}{|l|l|}
\hline$F_{r 1 x}$ & Rolling resistance force \\
\hline$F_{r 2 x}$ & Rolling resistance force \\
\hline$F_{a v}$ & Normal force \\
\hline$F_{a r}$ & Normal force \\
\hline$F_{a}$ & Aerodynamic force \\
\hline$F_{p r o p}$ & Thrust force \\
\hline$F_{p}$ & Gravity force \\
\hline$F_{m}$ & Motor force \\
\hline$\theta$ & Slope angle with the horizontal \\
\hline
\end{tabular}

Table 1. Applied forces to EV

\subsection{Aerodynamic force}

Aerodynamic drag is caused by the momentum loss of air particles as they flow over the hood of the vehicle. The aerodynamic drag of a vehicle can be modeled using the following equation:

$$
F_{2}=\frac{1}{2} \rho S_{f} C_{x} V^{2}
$$

\subsection{Gravity force}

The gravity force can be calculated as follows:

$$
F_{3}=M_{v} g \sin \theta
$$

\subsection{Motor force}

Using Newton's Second Law, we can deduce the motor force; it can be obtained by the following equation:

$$
M_{v} \frac{d V}{d t}=\sum \overrightarrow{F_{e x t}}=\overrightarrow{F_{m}}+\overrightarrow{F_{p}}+\vec{F}_{a}+\vec{F}_{r}
$$


By projection on the $(\mathrm{O}, \mathrm{x})$ axis, we obtain:

$$
F_{m}=M_{v} \frac{d V}{d t}+F_{a}+F_{p}+F_{r}
$$

The power that the EV must develop at stabilized speed is expressed by the following equation:

$$
P_{\text {vehicle }}=F_{m} V=\left(F_{r}+F_{a}+F_{p}+M_{v} \frac{d V}{d t}\right) V
$$

We deduce the expression of the total torque by multiplying equation (5) with the wheel radius $R$ :

$$
C_{\text {vehicle }}=C_{r}+C_{a}+C_{p}+M_{v} R \frac{d V}{d t}
$$

Neglecting the mechanical losses in the gearbox, the electromagnetic torque $\mathrm{C}_{\mathrm{em}}$ developed by the motor is obtained by dividing the wheels torque $C_{\text {vehicle }}$ by the ratio reduction $r_{d}$.

$$
C_{e m}=\frac{1}{r_{d}}\left(C_{r}+C_{a}+C_{p}+M_{v} R \frac{d V}{d t}\right)
$$

Figure 2 presents the dynamic model of the EV load, implemented under Matlab/simulink.

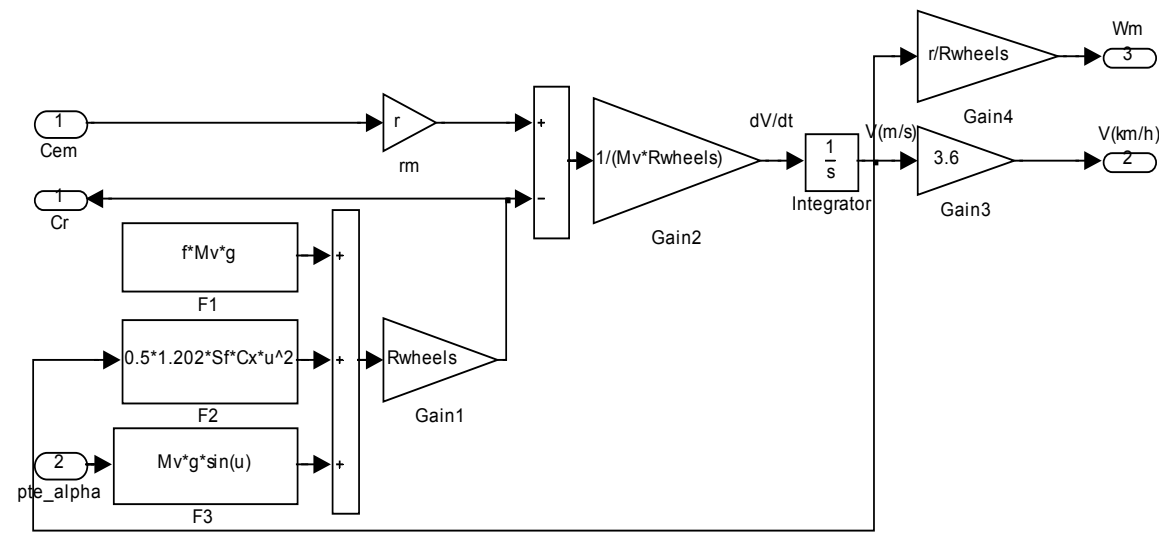

Fig. 2. SIMULINK dynamic model of electric vehicle

\section{Electric motor control}

Control of permanent magnet synchronous motor is performed using field oriented control. The stator windings of the motor are fed by an inverter that generates a variable frequency variable voltage. The frequency and phase of the output wave are controlled using a position sensor as shown in figure 3 .

In our studie, we have used two types of current control, Hysteresis and PWM. 


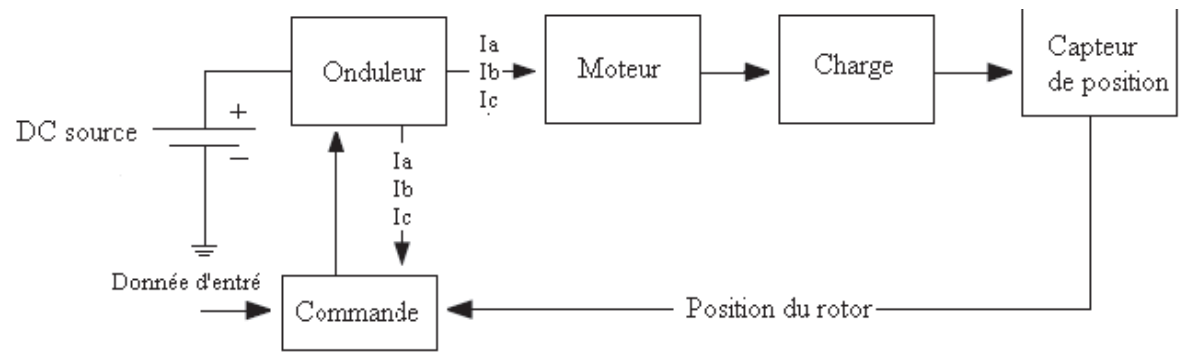

Fig. 3. Drive system schematic

\subsection{PWM current controller}

PWM current controllers are widely used. The switching frequency is usually kept constant. They are based in the principle of comparing a triangular carrier wave of desire switching frequency and is compared with error of the controlled signal [Bose, 1996].

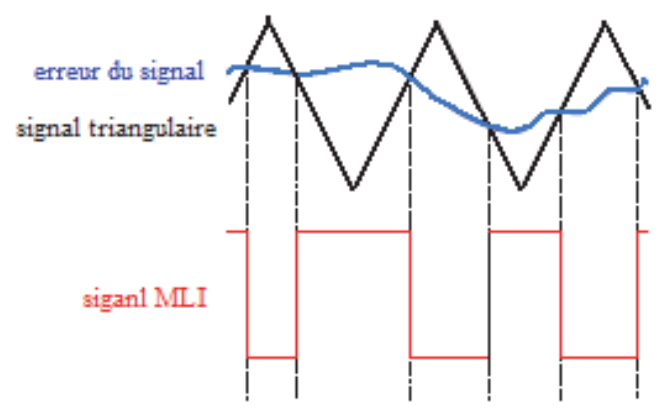

Fig. 4. PWM current controller

\subsection{Hysteresis current controller}

Hysteresis current controller can also be implemented to control the inverter currents. The controller will generate the reference currents with the inverter within a range which is fixed by the width of the band gap [Bose, 1996; Pillay et al., 1989].

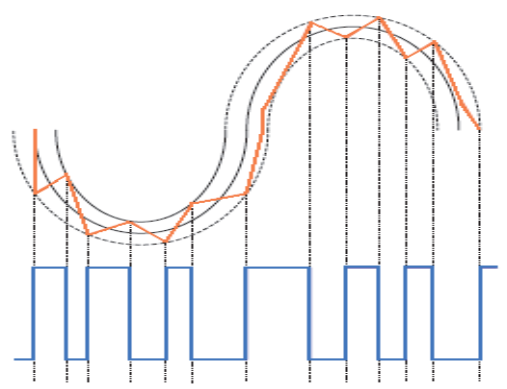

Fig. 5. Hysteresis current controller 


\section{Thermal model of IGBT module}

The studied module is the Semikron module SKM 75GB 123D (75A/1200V) which contains two IGBTs and with two antiparallel diodes. The structure of the module contains primarily eight layers of different materials, each one of it is characterized by its thickness Li, its thermal conductivity Ki, density $\rho$ i and its heat capacity Cpi. Table 2 show the materials properties of the various layers of module as shown in figure 6. These values are given by the manufacturer and/or of the literatures [Dorkel et al., 1996; Uta et al., 2000; Thoams et al., 2000].

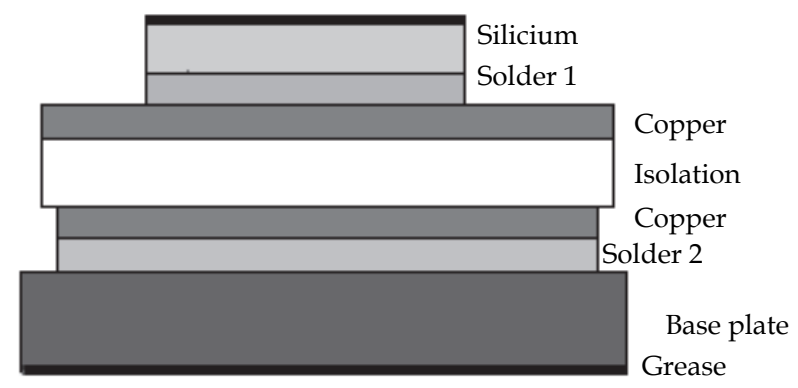

Fig. 6. Example of the module structure

\begin{tabular}{|l|c|c|c|}
\hline Material & $L(\mathrm{~mm})$ & $K(\mathrm{~W} / \mathrm{mK})$ & $\rho C p\left(\mathrm{~J} / \mathrm{Kcm}^{3}\right)$ \\
\hline Silicium & 0.4 & 140 & 1.7 \\
\hline Solder 1 & 0.053 & 35 & 1.3 \\
\hline Copper & 0.35 & 360 & 3.5 \\
\hline Isolation & 0.636 & 100 & 2.3 \\
\hline Copper & 0.35 & 360 & 3.5 \\
\hline Solder 2 & 0.103 & 35 & 1.3 \\
\hline Base plate & 3 & 280 & 3.6 \\
\hline Grease & 0.1 & 1 & 2.1 \\
\hline
\end{tabular}

Table 2. Thermal parameters of a power module

In the power module, the heating flow diffuses vertically and also laterally from the heating source. So, a thermal interaction happens inside the module between the adjacent devices when they operate together.

This thermal interaction depends from [Kojima et al., 2006; Ayadi et al., 2010; Fakhfakh et al., 2010]:

- The dissipated power value of the various components.

- The disposition of the chip components.

- The boundary condition at the heat spreader.

Figure 7 shows the thermal influence between the different components of the module. We notice that each component has a thermal interaction with the others and we supposed that each module have zero interaction with other modules. 


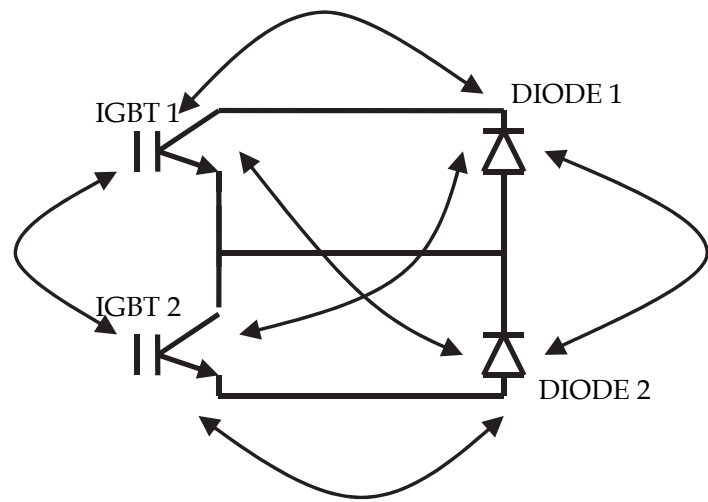

Fig. 7. Different thermal influences between the module components

Literature proposes some thermal circuit networks for electrothermal simulation for the semiconductor device. For example the finite difference method (FDM) and the finite element method (FEM). In our study we have used the FEM technique to model our inverter module. Figure 8 shows the thermal circuit example obtained by the FEM of IGBT1 without thermal interaction.

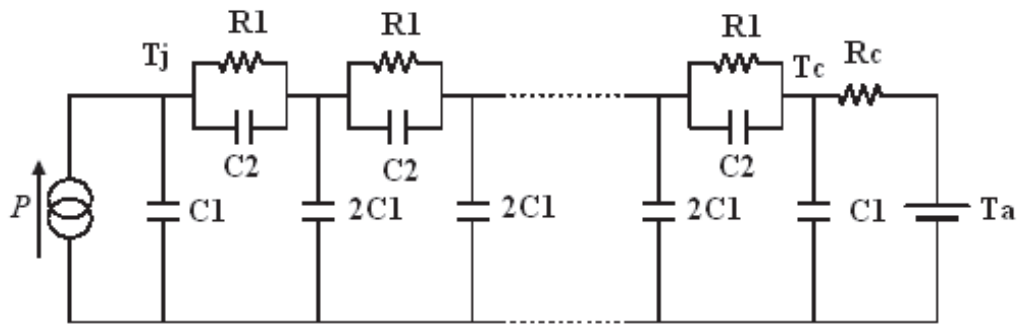

Fig. 8. Thermal circuit obtained by the FEM

Where:

- $\quad P$ is the input power dissipation device.

- $\quad \mathrm{T} j$ is the junction temperature.

- $\quad \mathrm{R} 1$ is the thermal resistance.

- $\quad$ Rc is the convection resistance.

- $\quad \mathrm{C} 1$ and $\mathrm{C} 2$ are thermal capacitance.

- Ta is the ambient temperature.

In order to introduce the thermal interaction between the different components of the module, we inserted three other current sources P1, P2 and P3. These sources are deduced from the structure of IGBT module [Drofenik et al., 2005; Hamada et al., 2006; Usui et al., 2006].

The source P1 is the power loss of DIODE1; it is introduced at the interface between the silicon and the copper materials because the IGBT1 and the DIODE1 ships are bounded on the same copper area. The source P2 and P3 are power loss of IGBT2 and DIODE2, they 
are introduced between solder 2 and base plate because all module components have the base plate as a common material. So the thermal circuit network of IGBT1 becomes as the figure 9 .

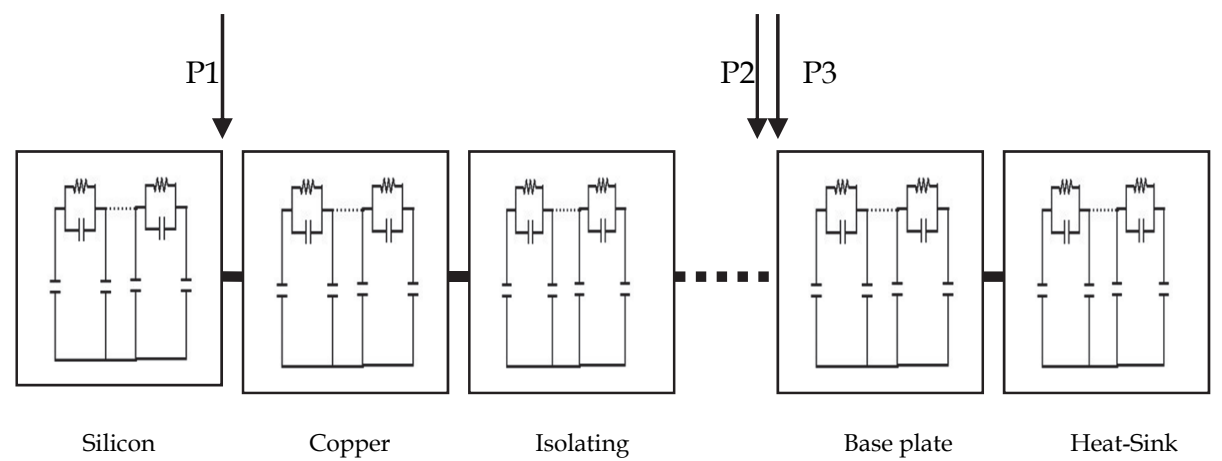

Fig. 9. Thermal model of IGBT module

\section{Simulation and results}

The PM motor drive simulation was built in several steps like abc phase transformation to dqo variables, calculation torque and speed, and control circuit [Ong, 1998; Roisse et al., 1998].

Parks transformation used for converting Iabc to Idq is shown in figure 10 and the reverse transformation for converting Idq to Iabc is shown in figure 11.

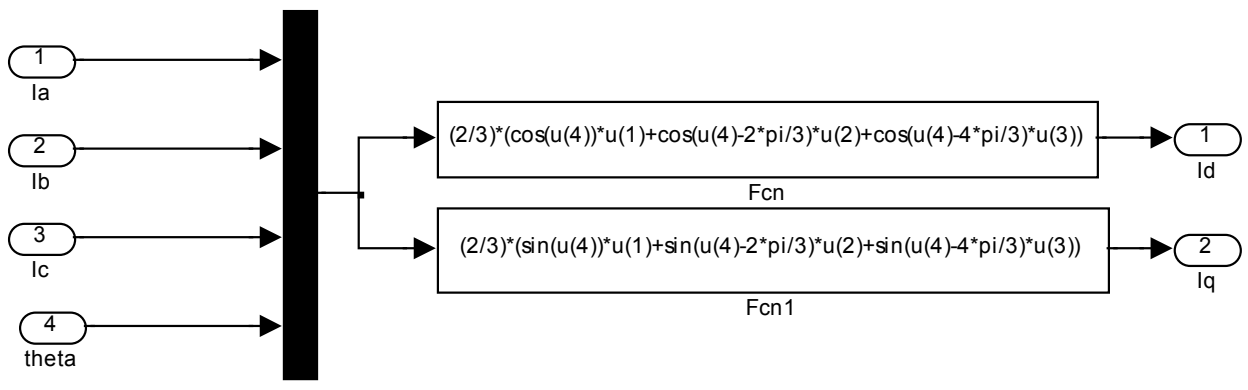

Fig. 10. Iabc to Idq bloc

The inverter is implemented in Simulink as shown in figure 12. The inverter consists of the "universal bridge" with the parameters of the IGBT module studied. All the voltages and the currents in the motor and the inverter can be deducted. The following figure shows the model of the inverter used.

For proper control of the inverter using the reference currents, current controllers are implemented generate the gate pulses for the IGBT's. Current controllers used are shown in figure 13 and 14 . 


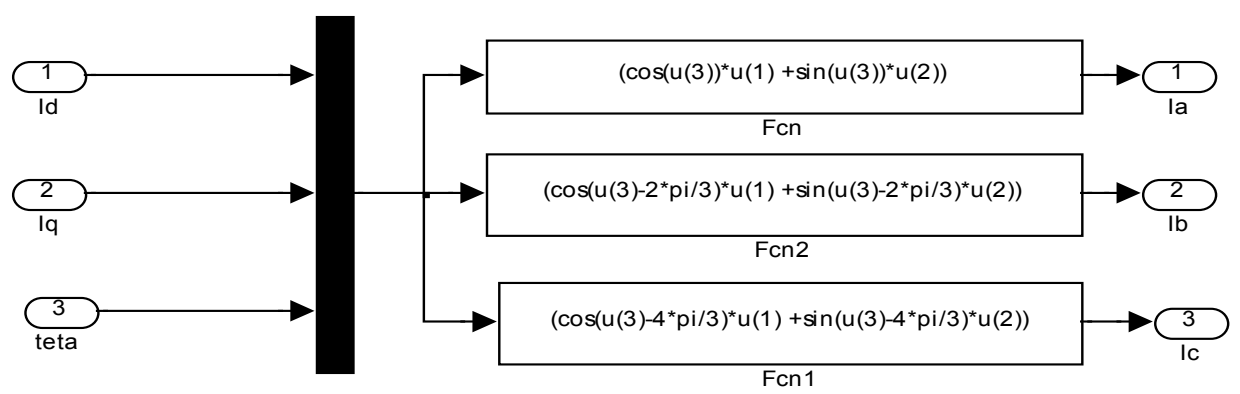

Fig. 11. Idq to Iabc bloc

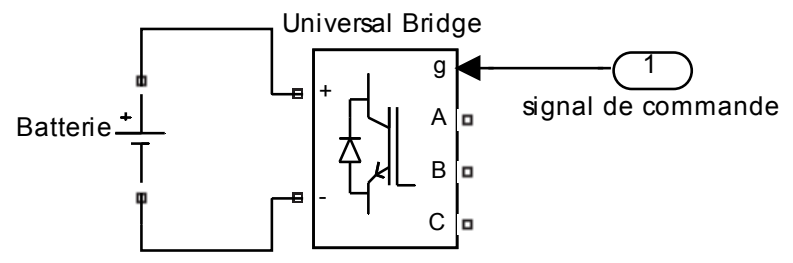

Fig. 12. Inverter model

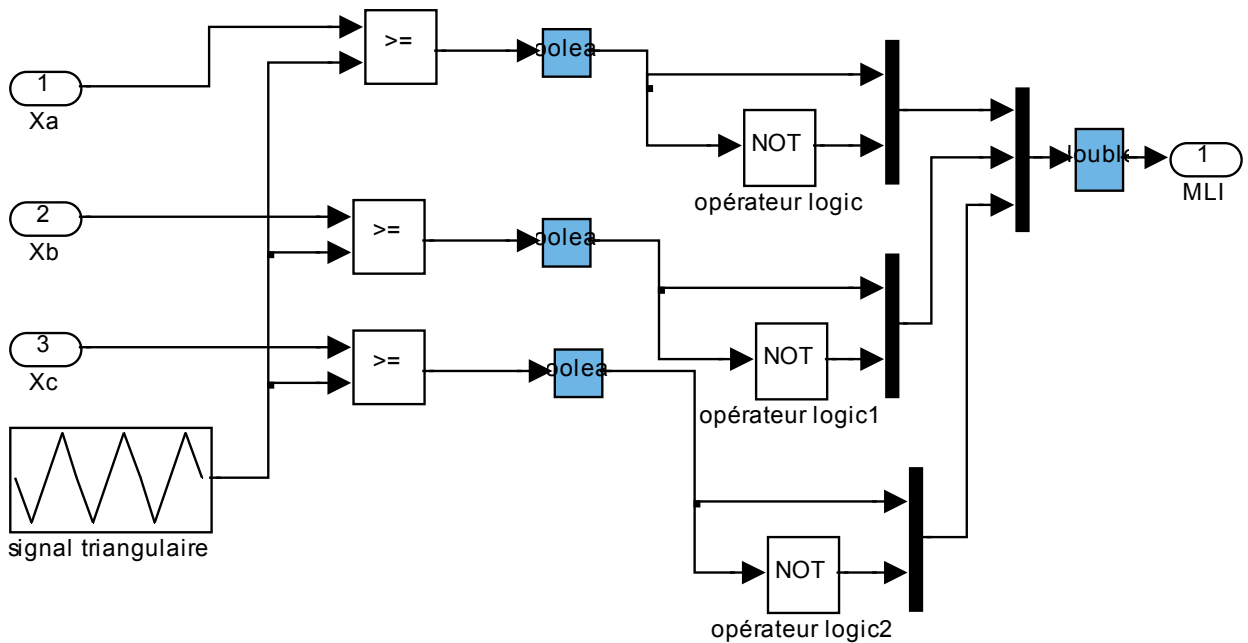

Fig. 13. PWM current controller 


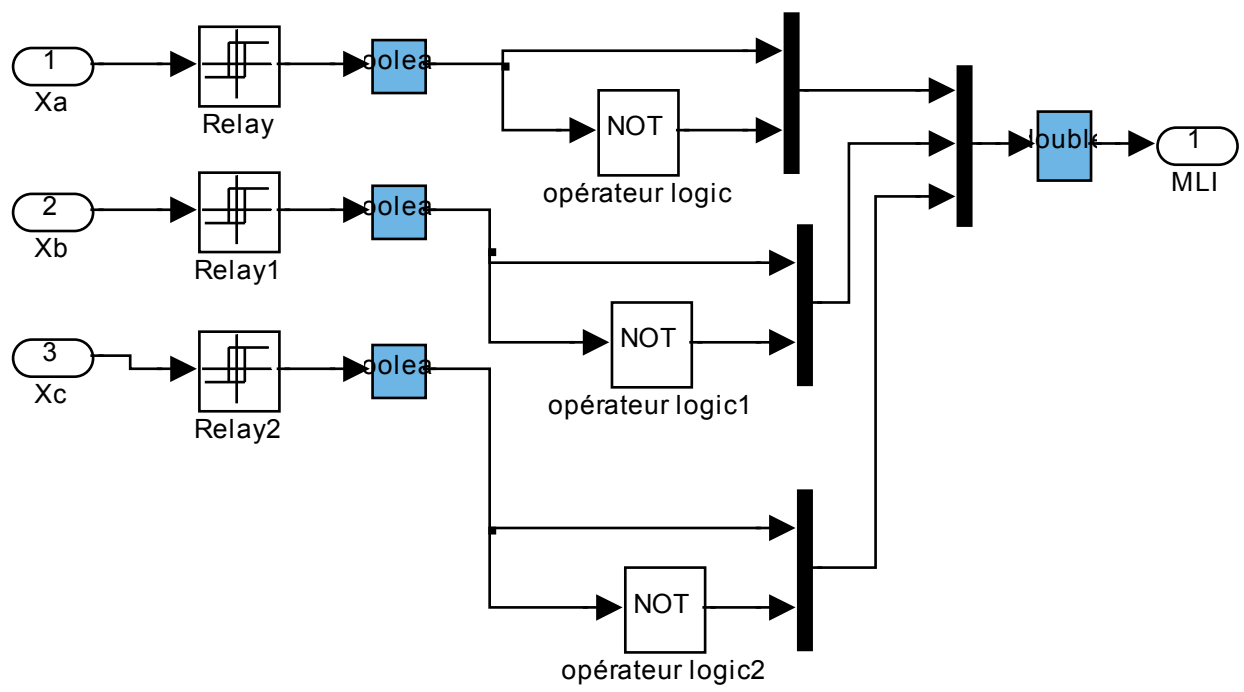

Fig. 14. Hysteresis controller

The complete system used for simulation and implemented in MATLAB / Simulink, is shown in Figure 15. This system was tested with two current controls, hysteresis and PWM control. The motor used is an axial flux Permanent Magnet Synchronous Motor (PMSM). For the simulation, we controlled the speed of EV at $30 \mathrm{~km} / \mathrm{h}$.

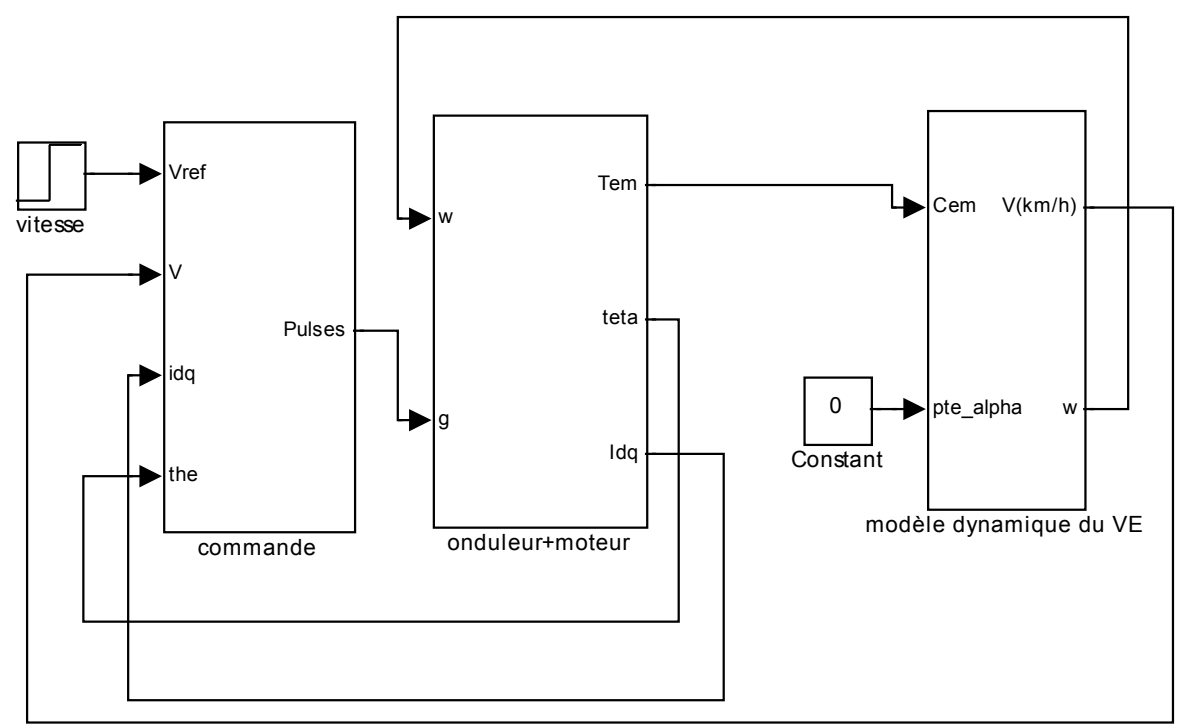

Fig. 15. PMSM in a traction chain 
Figure 16 shows the EV speed regulated at $30 \mathrm{~km} / \mathrm{h}$ for the two types of control. We note that with the hysteresis control, we reach faster the steady state.

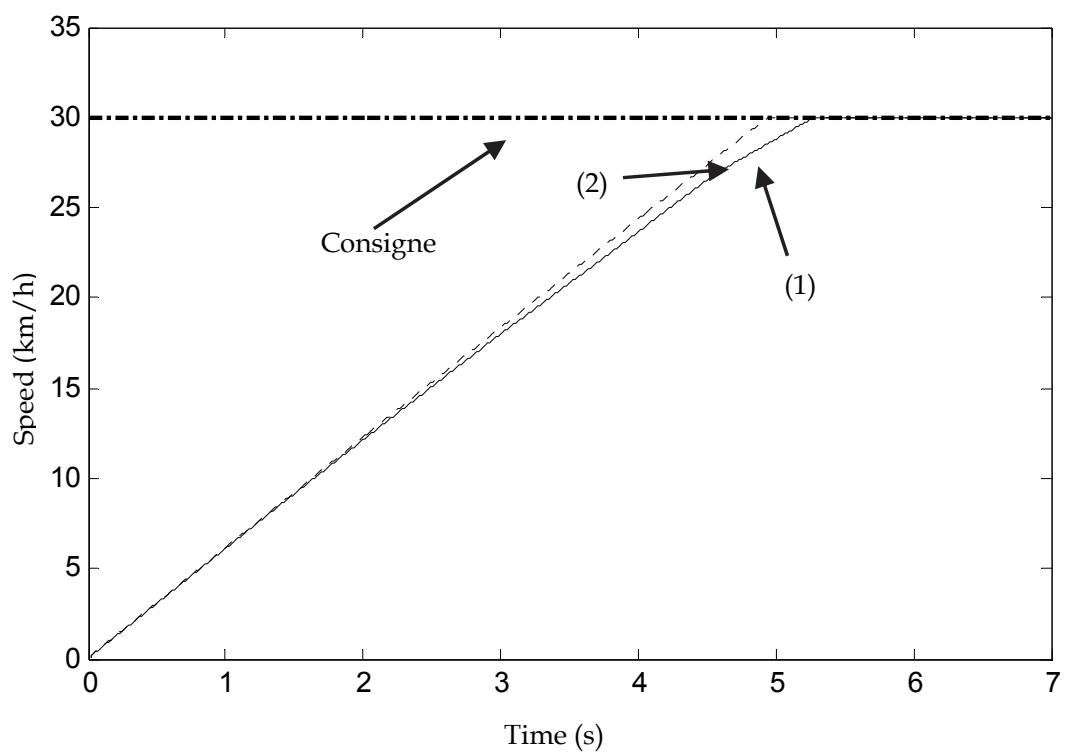

Fig. 16. EV speed; (1): with PWM controller; (2): with hysteresis controller

The stator phase currents corresponding to this regulation are represented by figure 17 and 18 Figure 19 and 20 show the IGBT1 and DIODE1 power losses for hysteresis and PWM current control respectively.

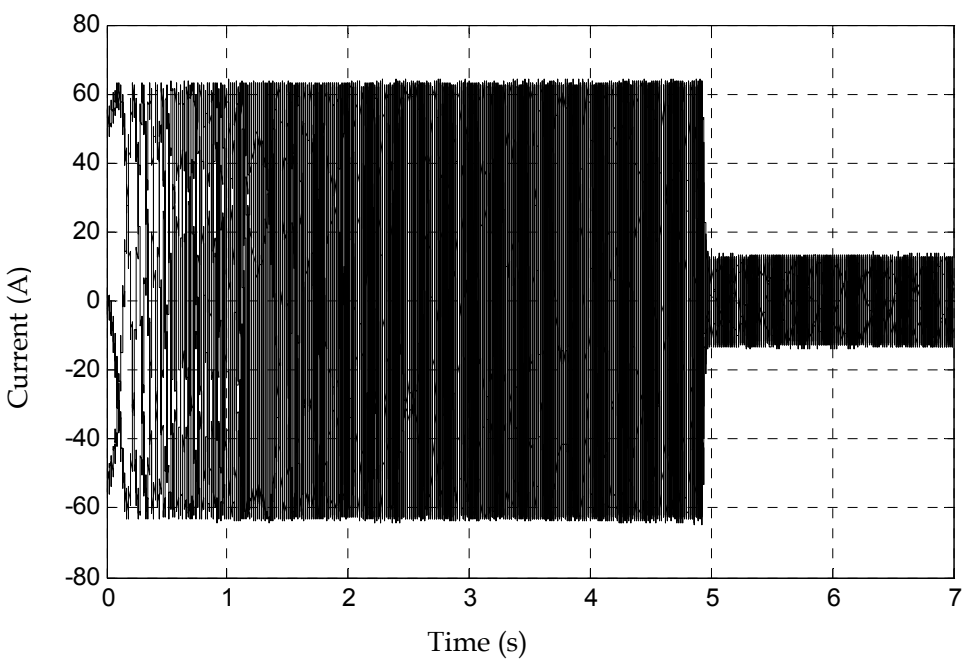

Fig. 17. Iabc currents with hysteresis control 


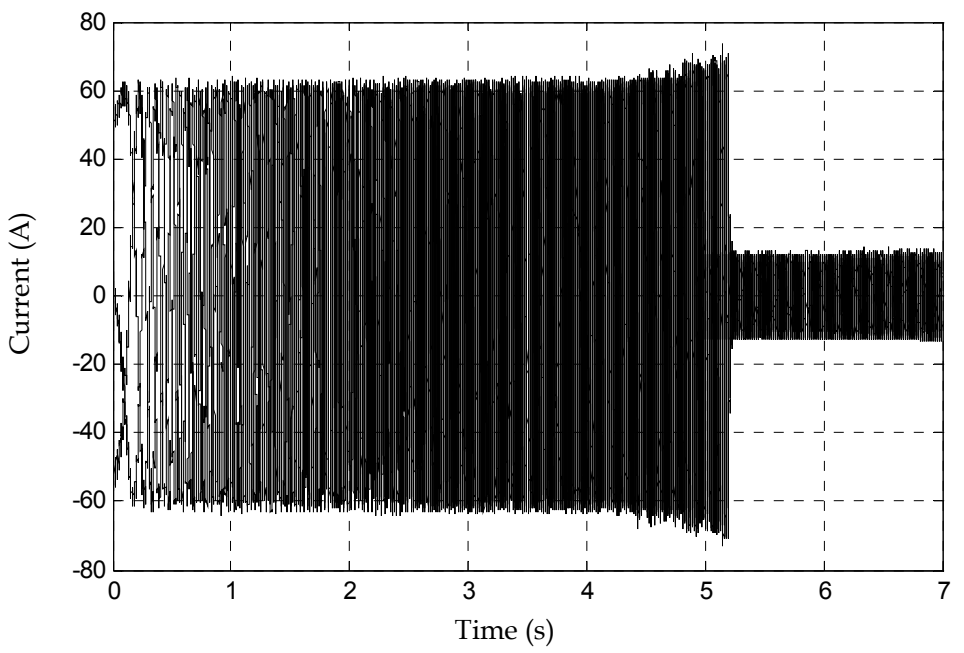

Fig. 18. Iabc currents with PWM control

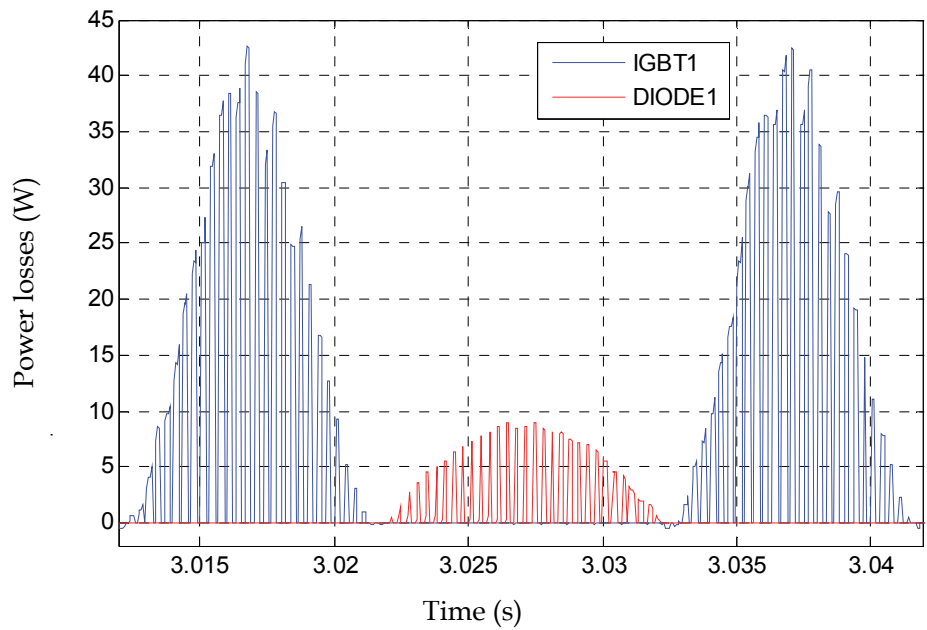

Fig. 19. IGBT1 and DIODE1 power losses with PWM control 


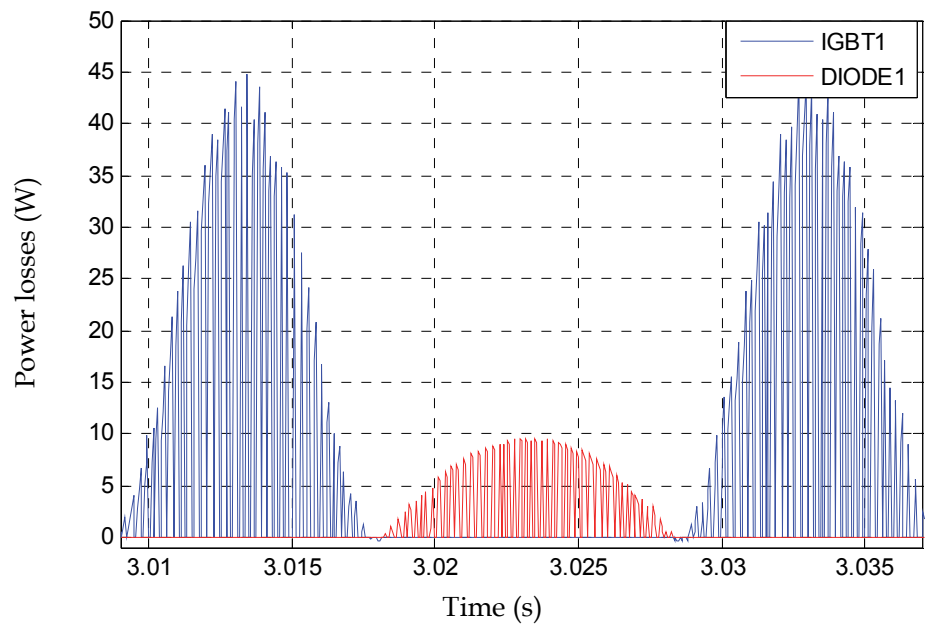

Fig. 20. IGBT1 and DIODE1 power losses with hysteresis control

Figure 21 and 22 show the IGBT1and DIODE1 junction temperature obtained by the two types of current control. It is very clear that the junction temperature of IGBT1 and DIODE1 is higher for the hysteresis control; this is due by the increase of power dissipation of the module components this type of control.

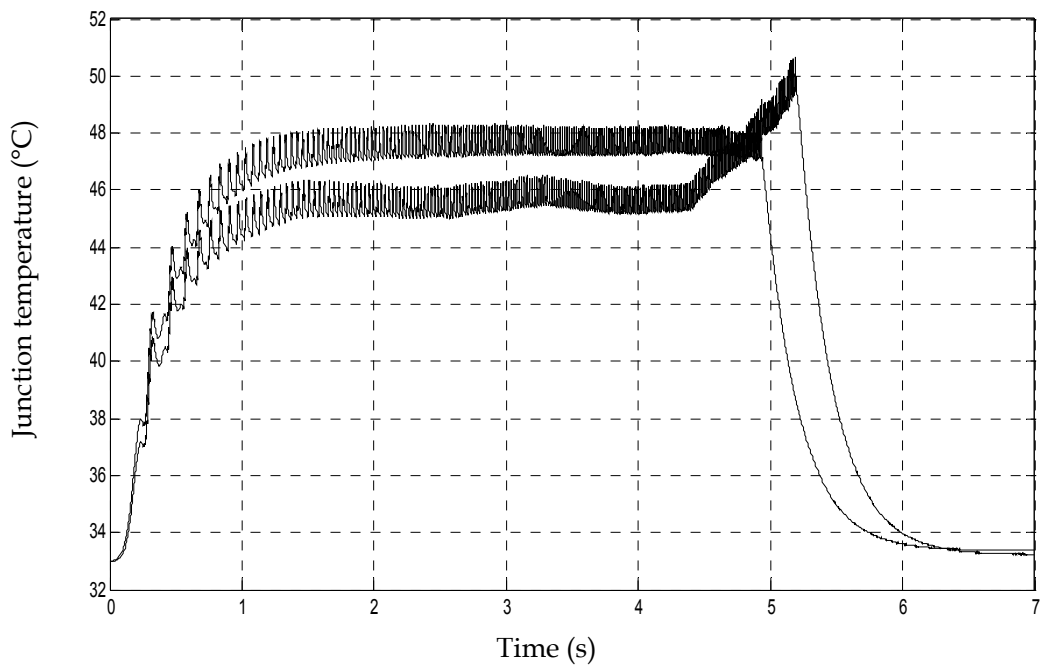

Fig. 21. IGBT1 junction temperature 


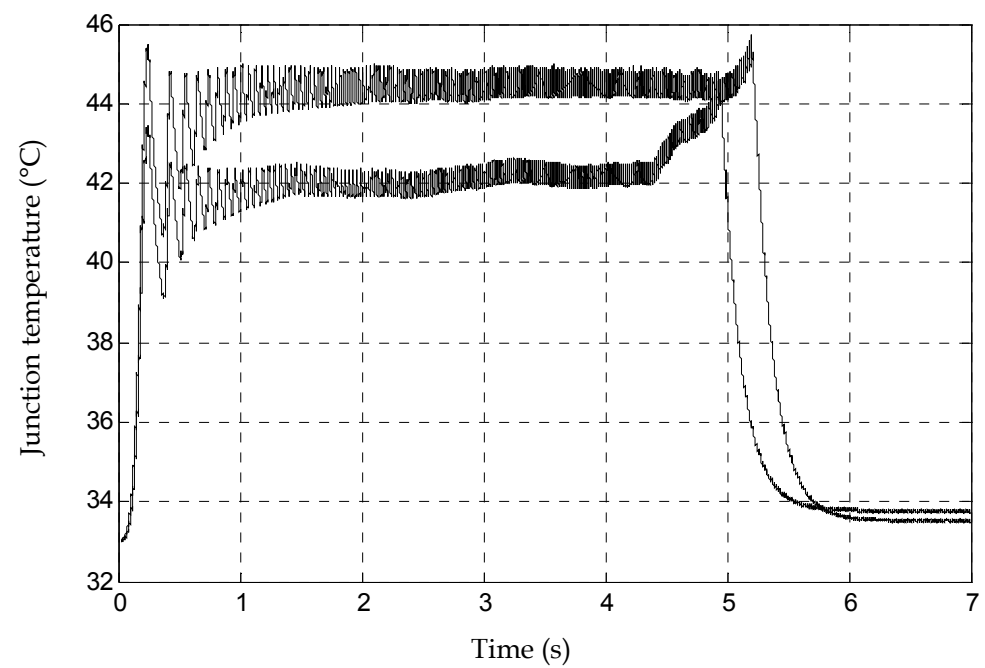

Fig. 22. DIODE1 junction temperature

\section{Conclusion}

A detailed dynamic model for EV was studied using two current control systems. MATLAB / Simulink were chosen from several simulation tools because of its flexibility in working with analog and digital devices, it is able to represent real-time results with the simulation time reduced. A comparative study was carried out in terms of switching frequency for power dissipated by the components of the inverter and junction temperature. The hysteresis current control has a variable switching frequency that depends on the hysteresis band, this type of control allows for fast simulations with a shorter time. The PWM current control has a fixed frequency switching and allows having junction temperatures lower than the hysteresis control.

\section{References}

B. K. Bose, Power Electronics and Variable Frequency Drives. (1996). 1 ed: Wiley, John \& Sons

P. Pillay \& R. Krishnan. (1989). Modeling, simulation, and analysis of permanent-magnet motor drives. I. The permanent-magnet synchronous motor drive. Industry Applications, IEEE Transactions on, vol. 25, pp. 265-273

Jean-Marie Dorkel, Patrick Tounsi, \& Philippe Leturcq. (1996). Three-Dimensional thermal Modeling Based on the Two-Port Network Theory for Hybrid or Monolithic Integrated Power Circuits. IEEE Transaction on Electronics Devices, vol. 19, NO. 4, pp. 501-507

Uta Hecht \& Uwe Scheuermann. (2000). Static and Transient Thermal Resistance of Advanced Power Modules. Semikron Elektronik GmbH, Sigmundstr. 200, 90431 Nürnberg (Germany). 
Thomas Stockmeier. (2000). Power semiconductor packaging-a problem or a resource? From the state of the art to future trends. Semikron Elektronik GmbH, Sigmundstr. 2000, 90431 Nürnberg (Germany)

M. Ayadi, M.A. Fakhfakh, M. Ghariani, \& R. Neji. (2010). Electrothermal modeling of hybrid power modules. Emerald, Microelectronics International (MI), volume 27, issue 3, 2010, pp. 170-177

M.A. Fakhfakh, M. Ayadi, and R. Neji. Thermal behavior of a three phase inverter for EV (Electric Vehicle). in Proc of 15th IEEE Mediterranean Electromechanical Conference (MELECON'10), Valletta, Malta, April 25-28, 2010, C4P-E24-3465, pp.1494-1498.

Kojima, et al. Novel Electro-thermal Coupling Simulation Technique for Dynamic Analysis of HV (Hybrid Vehicle) Inverter. Proceedings of PESCO6, pp. 2048-2052, 2006.

Hamada. Novel Electro-Thermal Coupling Simulation Technique for Dynamic Analysis of HV (Hybrid Vehicle) Inverter," Proc. of 7thIEEE Power Electronics Specialists Conference (PESC 2006), pp.2048-2052, 2006

U. Drofenik \& J. Kolar. (2005). A Thermal Model of a Forced-Cooled Heat Sink for Transient Temperature Calculations Employing a Circuit Simulator. Proceedings of IPECNiigata 2005, pp. 1169-1177, 2005

M. Usui, M. Ishiko, "Simple Approach of Heat Dissipation Design for Inverter Module," Proc. of International Power Electronics Conference (IPEC 2005), pp. 1598-1603, 2005.

C. M. Ong. (1998). Dynamic simulation of electric machinery using MATLAB/Simulink.

H. Roisse, M. Hecquet, P. Brochet. (1998). Simulation of synchronous machines using a electric-magnetic coupled network model. IEEE Trans. on Magneticss, vol.34, pp.3656-3659, 1998. 


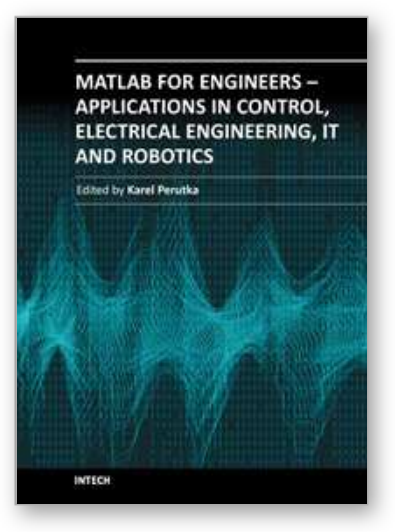

\section{MATLAB for Engineers - Applications in Control, Electrical Engineering, IT and Robotics}

Edited by Dr. Karel Perutka

ISBN 978-953-307-914-1

Hard cover, 512 pages

Publisher InTech

Published online 13, October, 2011

Published in print edition October, 2011

The book presents several approaches in the key areas of practice for which the MATLAB software package was used. Topics covered include applications for: -Motors -Power systems -Robots -Vehicles The rapid development of technology impacts all areas. Authors of the book chapters, who are experts in their field, present interesting solutions of their work. The book will familiarize the readers with the solutions and enable the readers to enlarge them by their own research. It will be of great interest to control and electrical engineers and students in the fields of research the book covers.

\section{How to reference}

In order to correctly reference this scholarly work, feel free to copy and paste the following:

Mohamed Amine Fakhfakh, Moez Ayadi, Ibrahim Ben Salah and Rafik Neji (2011). Thermal Behavior of IGBT Module for EV (Electric Vehicle), MATLAB for Engineers - Applications in Control, Electrical Engineering, IT and Robotics, Dr. Karel Perutka (Ed.), ISBN: 978-953-307-914-1, InTech, Available from:

http://www.intechopen.com/books/matlab-for-engineers-applications-in-control-electrical-engineering-it-androbotics/thermal-behavior-of-igbt-module-for-ev-electric-vehicle-

\section{INTECH}

open science | open minds

\section{InTech Europe}

University Campus STeP Ri

Slavka Krautzeka 83/A

51000 Rijeka, Croatia

Phone: +385 (51) 770447

Fax: +385 (51) 686166

www.intechopen.com

\section{InTech China}

Unit 405, Office Block, Hotel Equatorial Shanghai

No.65, Yan An Road (West), Shanghai, 200040, China

中国上海市延安西路65号上海国际贵都大饭店办公楼405单元

Phone: +86-21-62489820

Fax: +86-21-62489821 
(C) 2011 The Author(s). Licensee IntechOpen. This is an open access article distributed under the terms of the Creative Commons Attribution 3.0 License, which permits unrestricted use, distribution, and reproduction in any medium, provided the original work is properly cited. 